\title{
UN Resolution 1483 Occupational Mandate and Limitations to the Obligations of US Forces in Iraq
}

\author{
Nte Timothy U. (PhD) \& Achinulo, E. C. \\ Department of Political \& Administrative Studies, University of Port Harcourt, Nigeria
}

\begin{abstract}
The formal acknowledgement of their status, responsibilities and obligations as the occupying power makes the US occupation of Iraq which began in April 21, 2003 unique. It marked the first instance since the inception of the UN that the invader or aggressor is acknowledging and accepting responsibilities as an occupier and the UN is given approval to the situation. UNSC Resolution 1483 was unanimously approved on May 22, 2003 to validate the occupation mandate in Iraq. It was interpreted in consonance with relevant provisions of The Hague Regulations and the 4th Geneva Conventions. Equipped with these legal documents this article weighs the performance of the US in her military occupation of Iraq. It concludes that there were enormous limitations on the US to meet up their responsibilities and obligations as occupying power in Iraq. It recommends that aggression and invasion of sovereign states should remain abrogated. When war inevitable occurs and there is military occupation; occupying powers should conscientiously adhere to the responsibilities and obligations embedded in the international law of occupation.
\end{abstract}

Keywords: Occupational Mandate, Limitations, Obligations, US, Iraq

\section{Introduction}

Military occupation has legal consequences and responsibility and the unique thing about the occupation of Iraq was that the United States of America and her coalition formally acknowledged their status, responsibilities and obligations as occupying powers. What distinguishes Iraq from other instances of foreign occupation was that the occupation of Iraq represents the first instance since the inception of the United Nations that the invader or aggressor is acknowledging and accepting responsibilities as an occupier and the United Nations is given approval to the situation.

The occupation of Iraq actually started on April 21, 2003 when the forces of the United States of America and her coalition created the Coalition Provisional Authority (CPA) sequel to the fall of Baghdad. However the legitimization of the occupation was on May 22, 2003 when the United Nations Security Council passed Resolution 1483.

The United Nations Security Council Resolution 1483 validates the occupation mandate in Iraq. Resolution 1483 was unanimously approved on May 22, 2003 by the United Nations Security Council. It was interpreted in accordance with relevant provisions of The Hague Regulations and the 4th Geneva Conventions.

Much of the issues about the process and prospects of the law of occupation is embedded in the international law of occupation which is a body of rules designed to provide a legal framework and regulate the way in which an occupying power governs occupied territory. It is hinged on the Hague Regulations concerning the Laws and Customs of War on Land and the 4th Geneva Convention which revolves around the Protection of Civilian Persons during Times of War.

Equipped with these legal documents the article would weigh the performance of the United States of America in her military occupation of Iraq. It would explore and assess the fundamental obligations of the occupying forces in Iraq. The substantive question is to what extent did the United States of America meet up her responsibilities and obligations as stipulated by the law of military occupation?

\section{Occupation Mandate In Iraq And Un Resolution 1483}

The unique thing about the belligerent occupation of Iraq is that it is the first case of the United Nations formally endorsing an occupation and the occupying forces accepted their responsibilities and obligations under customary international law. The United Nations Security Council Resolution 1483 validates the occupation mandate in Iraq. Resolution 1483 was unanimously approved on May 22, 2003 by the United Nations Security Council.

It was quintessential in the sense that it was the very first $\mathrm{UN}$ resolution to authorize and regulate belligerent occupation. According to Clark (2005:22) it is "the most comprehensive and innovative Security Council mandate on the governance of an occupied territory ever issued by the UN." The United Nations Security Council made it clear that "the entire resolution be read and interpreted in accordance with relevant provisions of The Hague Regulations and the 4th Geneva Conventions." (ibid). The resolution covers activities 
like reconstruction, humanitarian aid, and the creation of a new government. It created a new Developmental Fund that would collect funds from the sales of Iraqi oil. The resolution was subject to review after a one year period.

Some of the very unique features of Resolution 1483 are that it reiterates the fact that sovereignty does not pass to the occupier because she has been completely defeated in war. Resolution 1483 makes it evidently clear that the fall of the Iraqi government did not affect the sovereignty and territorial integrity of Iraq. It also acknowledges the fact that international humanitarian law must be applied by the occupying forces. According to Clark (2005:2)

"Benvenisti has highlighted four unique features of resolution 1483: 1. It expressly refutes the claim that occupation as such is illegal. 2. It confirms the notion that sovereignty does not pass to the occupier on the total defeat and disintegration of the governing regime. 3. It affirms the continued applicability of international human rights law to the territory in spite of foreign occupation. 4. It calls on the occupiers to pursue effective administration and fulfil their duties (such as the protection of the occupied population), rather than merely being an 'inactive custodian' of occupied territory

Other aspects of resolution 1483 are that it recognized the creation of a transitional governing council of Iraqis; and removed all sanctions against Iraq that were placed upon the former regime of Saddam Hussein. The resolution mandated the transfer of power to authorize expenditures from Iraq's oil revenue from the United Nations to a Development Fund for Iraq. The arrangement was that effective May 23, 2003 the fund would be controlled by the Coalition Provisional Authority. The resolution also created a multinational body, known as the International Advisory and Monitoring Board, to monitor and evaluate the expenditures of the CPA from the oil revenue of Iraq. In order to curtail abuse or fraudulent use of Iraq's oil proceeds the Coalition's authority to expend revenue derivable from Iraq's oil was conditional.

The challenges and suspicion of defrauding or misappropriating the fund from Iraq's oil was taken care of in the Article 20 of the resolution which states that:

"all export sales of petroleum, petroleum products, and natural gas from Iraq following the date of the adoption of this resolution shall be made consistent with prevailing international market best practices, to be audited by independent public accountants reporting to the International Advisory and Monitoring Board ... in order to ensure transparency, [and that] all proceeds from such sales shall be deposited into the Development Fund for Iraq until such time as an internationally recognized, representative government of Iraq is properly constituted;"

There is also the vital innovation in Resolution 1483 which sets up a monitoring process to oversee the occupant's measures. This monitoring process was instituted by the creation of the office of UN Special Representative for Iraq. The Special representative is independent of the occupying powers and is vested with the powers to oversee compliance with the law of occupation as well as other very important mediating functions. In line with the Special Representative provision; Article 8 of Resolution 1483 states that his independent responsibilities shall involve reporting regularly to the Council..." and "...coordinating activities of the United Nations in post-conflict processes in Iraq. According to Eyal (2004) "this is the first time the UN has had an independent supervisory role during a belligerent occupation."

Resolution 1483 may be considered as the latest and most authoritative affirmation of a host of fundamental norms, rules and regulations on the law of occupation. It portrays belligerent occupation as a statutorily regulated process and that sovereignty is a fundamental entitlement of the people even when occupied. Consequently the overthrow or conquest of a regime does not ostracise sovereignty. The implication is that the occupying forces must (as stated in the preamble of Resolution 1483) act "effectively" to promote the "welfare" of the occupied ... and to create condition for the people's establishment of a new political institutions based on their free will, which will also ensure "equal rights and justice to all Iraqi citizens without regard to ethnicity, religion, or gender."

The enactment of Resolution 1483 shows that the occupying forces have agreed to comply with the international rule of law with respect to their role as occupying powers; have accepted a UN role in post-war Iraq; have agreed to fulfil their obligations under the Geneva Conventions and Hague Regulations and have agreed to respect the sovereignty of the people of Iraq including their rights to determine their own political future and exercise control over their natural resources. Most of these issues as discussed above are embedded in the articles of the Resolution.

Resolution 1483 was necessitated by the burning desire to commence the peaceful resolution, stabilization and political transition of Iraq from its war torn status to a standard that is conventional in international relations. The issue of restoring full sovereignty and political independence with respect to the Iraqis governing themselves was paramount in the resolution. Paragraph 4 of the Preamble (Resolution 1483) expresses the "resolve that the day when Iraqis govern themselves must come quickly"

The opening up of Iraq to international trade, liberalization of it economy and similar, handing over of the administration of the area to the occupiers and other similar articles of Resolution 1483 have attracted 
criticism. Some scholars believe that these actions were taken so that the US can reap bountifully from the very huge and rich oil minerals resources of Iraq. According to Paine (2007 Nov 16) "the Security Council passed Resolution 1483, which recognized the role of the occupying powers and turned over to them control of Iraq's oil export revenues." The impression here is that the most spectacular achievement of Resolution 1483 for the occupying powers is that they were given the mandate to control Iraqi oil, which is the primary undertone for the invasion. According to Khan (2003:18) "...those who argued that the goal of going it alone was seizing Iraq's oil, and not Iraq's liberation, find ample proof in the substance of that Resolution"

Despite the fact that Resolution 1483 demands the occupying forces to comply with their obligations under international law some critics of Resolution 1483 allege that it is not comprehensive enough because it ought to make proviso for indictment if the obligations are not accomplished. Also provision should have been made for payment of reparations for war damage since the war has been declared illegal. According to Clark (2005:11) "it has been criticised for not expressly stating that the occupiers are to pay for war damage and reconstruction costs in Iraq".

It has to be noted that "treaty law of occupation and the law of armed conflict do not state that occupying powers must pay for war damage or compensate victims of war" (ibid). Some scholars are however of the view that in circumstances were a case of illegality in the invasion of Iraq is established by the International Court of Justice (ICJ) or a competent international military tribunal (similar to the Nuremberg Military Tribunal); that the United States of America should be held liable to pay reparations under the principles of state responsibility.

As we noted above the major feature of Resolution 1483 is that the United Nations Security council gave the mandate for the belligerent occupation of Iraq to the US. This mandate was designed to expire after one year. Unfortunately the occupying forces (the US and her coalition) were not able to meet these obligations within the stipulated time frame. The military occupation that was scheduled to last for one year in consonance with the law of occupation was extended from May 2004, to May 2005 and much more. The United Nations have to extend the mandate of belligerent occupation on Iraq by the United States of America because she was not meeting up. According to Tremblay (Jun 18, 2008) "the United Nations was forced to extend a mandate of occupation to the United States. Thus, in June 2004, the U.N. Security Council adopted Resolution 1546 that recognized the de facto occupation of Iraq by American-led military forces..."

The new mandate as ratified by Resolution 1546 was designed to expire by the end of 2005 but was again extended. According to Paine (Nov 16, 2007) "The Council has renewed the MNF mandate three times, first with Resolution 1546 (June 8, 2004) which provided a more extensive description of the mandate. The subsequent renewals were adopted under Resolution 1637 (November 11, 2005) and Resolution 1723 (November 28, 2006). These extensions were indications of lapses or limitations on the part of an occupying force. The responsibilities and obligations of the United States of America as an occupying force in Iraq - were they achieved? To this we turn.

\section{Obligations Of Military Occupation And The Limitations Of Us Forces In Iraq}

This section would explore the validity and scope of the law of military occupation and how this can be reconciled with the obligations of the United States of America with respect to her occupation. The substantive question is to what extent is the United States of America meeting up her obligations as stipulated by the law of military occupation? It would explore and assess the fundamental obligations of the occupying forces in Iraq.

Let us start with the nomenclature of the law of Belligerent Occupation. Military Occupation refers to a situation where a state or territory is invaded and the invader takes over power control and authority from the legitimate government of the invaded state or territory. According to Article 42 of the Hague Convention, "territory is considered occupied when it is actually placed under the authority of the hostile army." The law of occupation delineates the duties and obligations of the occupiers and the occupied. This in turn enhances the efficacy of international humanitarian law.

Much of the issues about the process and prospects of the law of occupation is embedded in the international law of occupation which is a body of rules designed to provide a legal framework and regulate the way in which an occupying power governs occupied territory. The law of occupation becomes tenable when an occupying force like the United States of America takes over and exercises control and authority over a foreign territory like Iraq. According to Clarke (2005:8) "the key provisions of this body of law are found within Chapter 3 of both the Hague Regulations concerning the Laws and Customs of War on Land and the 4th Geneva Convention Relative to the Protection of Civilian Persons during Times of War (1949)".

These are also called Hague Regulations and the 4th Geneva Convention respectively. Articles 3 \& 4 of Protocol 1 Additional to the Geneva Conventions of 12 August 1949, and relating to the Protection of Victims of International Armed Conflicts are also listed as a major source for the law of occupation. The international law of occupation is however not confined to treaty law. Other sources include customary law, applicable domestic law, and $\mathrm{UN}$ resolutions. 
Military occupation has legal consequences and responsibility and the unique thing about the occupation of Iraq is that the United States of America and her coalition have formally acknowledged their status and obligations as occupying powers. Despite the well acclaimed acknowledgement the United States did not meet up because when territory is occupied; the occupying forces must comply with the law of occupation.

An analysis of some of the highlights of these obligations may throw more light on the limitations. First in this series is the Hague Regulations which was the first set of international rules governing the conduct for occupying forces. Article 1 of Hague Regulations (1907) provides that "The laws, rights, and duties of war apply not only to armies, but also to militia and volunteer corps..." The implication is that the law of military occupation applies to both the occupiers and the occupied.

Another watershed in the development of the law of occupation is the Geneva Conventions of 1949. This introduced international humanitarian law in general and consolidated the law of occupation. According to Robert (2005:253) "more vociferous obligations were imposed on occupiers, and a number of aspects of the law of military occupation that had not been resolved during the drafting of the Hague Regulations were addressed." It recommends in details the obligations of occupying forces with respect to protecting people in an occupied territory.

The general impression is that the Geneva Conventions would supplement the Hague regulations but they are part and parcel of the working documents which constitutes and dictates the legitimacy and obligations of military occupation. The 4th Geneva Convention affords protection to both combatants and non-combatants, both being persons protected by the convention. The rule of law stipulates that no one is above the law, every person, regardless of rank or allegiance, is subject to the law. This rule is not compromised even during a military occupation.

The United Nations Security Council Resolutions are legitimate legal backings for the rights and obligations for both the occupier and the occupied. As is the case with Resolution 1483 of Iraq; these resolutions may also either persuade or compel occupying forces to observe other international norms that are not peculiar to the law of occupation. The obligations of an occupying power should prevail whether or not it was lawful to use the armed force that resulted in the occupation. Clarke (2005:5) noted that "[ $t$ ] provision of security, basic necessities, and compliance with numerous other obligations owed to civilians under Articles 47-64 of the 4th Geneva Convention."

Beyond these obligations the United States of America had a broader range of responsibilities like duty to restore and maintain law and order; duty to respect public and private property; duty to protect the basic human rights of occupied peoples; administration of public property and institution; protection of religious and cultural property; duty to protect women; obligation to release Prisoners of War (POW); obligations regarding hospitals, public health and humanitarian assistance. There were great limitations with respect to accomplishing these obligations by the United States of America in her military occupation of Iraq.

In the course of the occupation there have being massive looting of cultural property and destruction of holy sites and Mosque. During the commotion that followed the collapse of Saddam Hussein's regime, looters entered the Iraq National Museum in Baghdad. According to Joffe (2004:31) "[t]hey stole and destroyed artifacts and caused damage to the museum. But as the confusion also enveloped the museum, no one outside Iraq knew exactly what was taken or the identity of the thieves". Buttressing the issue of lawlessness triggered by the invasion which got out of hand for the occupying forces Knickmeyer (Feb 23, 2006), noted that Bombers blasted the gilded dome of one of Shiite Islam's holiest shrines into naked steel and gaping blue sky Wednesday in a provocative assault that roused tens of thousands of Iraqi Shiites into angry protests and deadly clashes." These actions depict failure of the US and her coalition to meet up their obligations as stated in Article 56 of the Hague Regulations that "....all seizure of, or wilful damage done to institutions of this character, historic monuments, works of art and science, is forbidden, and should be made the subject of legal proceedings".

The forces of the United States of America did not also do enough in the area of protection of the human rights of the people of Iraq. Contrary to the responsibilities and obligations of the law of military occupation (See The Geneva Conventions Article 3 and Article 31); the United States forces subjected citizens to torture, and coercion, mutilation, killings, incarceration, imprisonment, corporal punishment etc. According to Croke (2007:1) "American legal investigators have discovered evidence of abuse, torture and rape throughout the US-run prison system in Iraq." Also the fact finding mission of a "Michigan Legal Team" gathered evidence supporting claims of prisoner abuse at some 25 US-run detention centres.

Women the world over are treated with dignity and reverence and there are obligations upon occupying powers to protect them. This is in consonance with the recommendations of Article 46 of The Hague Regulations and Article 27 of the $4^{\text {th }}$ Geneva Convention. These conventions stipulate that "Women must be especially protected against any attack to their honour - in particular from rape, enforced prostitution or any form of indecent assault." Unfortunately this was not the case in Iraq, for according to Rosen (2006:1) "a group of five American soldiers allegedly were involved in the rape and murder of Abeer Qassim Hamza, a young Iraqi girl. Her body was then set on fire to cover up their crimes, her father, mother, and sister murdered" 
Obviously this is a most heinous crime against humanity. There are incessant cases of rape, enforced prostitution, indecent assault, sexual crimes in captivity etc.

Prisoners of War and transfer of protected persons is another criterion for the assessment of the limitations of the United States of America with respect to their obligations under the law of military occupation. There are specific duties upon occupying power to ensure that protected persons, unlawful combatants and/or prisoners of war are not forcefully transferred from the occupied territory to any other place including the territory of the occupying power. This is as contained in Article 49 of the $4^{\text {th }}$ Geneva Convention and other articles of the Law of Occupation. The implication is that the Law of Occupation is opposed to transferring prisoners to Gauntanemo Bay.

According to Brown (Jul 13, 2006) "the US supreme court ruled today that the US president, George Bush, overstepped his authority in creating military war crimes trials for detainees at Guantánamo Bay. In a rebuke to the Bush administration, Justice John Paul Stevens said the proposed trials were illegal under US law and Geneva conventions."

This also applies to the release of prisoners of war at the end of hostilities. They are supposed to be released fairly and promptly. This is in accordance to Article 118 of the $3^{\text {rd }}$ Geneva Convention, which states that "Prisoners of war shall be released and repatriated without delay after the cessation of active hostilities." This was not the case in Iraq. It is a known fact that major combat operations in Iraq ended in May 2003. According to Hartmann (2006:1) "There is no longer war against Iraq. It ended in May of 2003, when George W. Bush stood below a 'Mission Accomplished' sign aboard the USS Abraham Lincoln and correctly declared that we had defeated the Iraqi army and overthrown their government." Years after 'mission accomplished' which marked the official end of the war thousands of prisoners of war were still in prison. This was a major limitation to the law of military occupation.

Another fundamental prerequisite of the law of military occupation is that occupying powers should provide for the health of occupied people without prejudice or discrimination. As specified in Article 56 of the $4^{\text {th }}$ Geneva Convention:

"To the fullest extent of the means available to it, the Occupying Power has the duty of ensuring and maintaining, with the cooperation of national and local authorities, the medical and hospital establishments and services, public health and hygiene in the occupied territory, with particular reference to the adoption and application of the prophylactic and preventive measures necessary to combat the spread of contagious diseases and epidemics".

Oxfam International recently conducted a research to determine the state of health facilities and other humanitarian services in Iraq. Based on this research a publication was made. According to Sengupta (Aug 18, 2007), the report revealed that:

"Many hospitals, and medical teaching facilities in Baghdad have lost up to 80 per cent of their teaching staff. The dossier says Iraq is suffering from an appalling and largely hidden humanitarian crisis, away from the daily bombings, with millions of people in desperate need of help"

Below are some analyses with respect to the accomplishment of the obligations of the military occupation in the light of The Hague Regulation, The Geneva Convention and UN Resolution 1483. Available data and international poll show the limitations of the US in her military occupation of Iraq.

$>$ On the question "Is the US meeting their occupational mandate obligation?" $90 \%$ responded that "The US

is not meeting their obligation". Poll of Iraq Centre for Research \& Strategic Studies (Nov 2006)

$>$ On the question "How much do you assess the US Occupational Government with respect to Economic development and Reconstruction" 95.8 responded Poor. Poll of Iraq Centre for Research \& Strategic Studies (Nov 2006)

$>$ On the question "What is your position on the economic situation in Iraq Today?" 79.3\% responded Worse. Poll of Iraq Centre for Research \& Strategic Studies (Nov 2006)

$>$ On the question "How much do you assess the US Occupational Government with respect to implementation of its obligations and promises?" $89.9 \%$ responded Very Poor. Poll of Iraq Centre for Research \& Strategic Studies (Nov 2006)

$>$ On the question "How much do you assess the US Occupational Government with respect to providing services?” 90.1\% responded Very Poor. Poll of Iraq Centre for Research \& Strategic Studies (Nov 2006)

$>$ On the question "Coalition Forces are responsible for any improvement in Security?" 99\% responded No. Poll taken by the British Ministry of Defence (Aug 2006)

$>$ On the question "Do you have confidence in the occupying forces?" $72 \%$ responded No Confidence. Poll taken by the British Ministry of Defence (Aug 2006)

$>$ Global population approval rating on the US handling of the Iraq War - 73\% Global population disapprove US handling of the Iraq war. Poll taken by BBC World Service (Sep 2007)

These are indications of great lapses and limitations on the part of an occupying force. 


\section{Conclusion And Recommendations}

Available data and international polls makes it crystal clear that there were enormous limitations on the United States of America to meet up their responsibilities and obligations as occupying power in Iraq. It recommends that aggression and invasion of sovereign states should remain abrogated. When war inevitable occurs and there is military occupation; occupying powers should conscientiously adhere to the responsibilities and obligations embedded in the international law of occupation. The international law of occupation is a body of rules designed to provide a legal framework and regulate the way in which an occupying power governs occupied territory. It is hinged on the Hague Regulations concerning the Laws and Customs of War on Land and the 4th Geneva Convention which revolves around the Protection of Civilian Persons during Times of War.

\section{References}

[1] Clarke Ben (2005 Aug), Military Occupation and the Rule of Law: The Legal Obligations of Occupying Forces in Iraq, Murdoch University Electronic Journal of Law, Murdoch

[2] Eyal Benvenisti (2003), The Security Council and the Law of Occupation: Resolution 1483 on Iraq in Historical Perspective, Tel Aviv University Interdisciplinary Research Centre, Tel Aviv

[3] Paine Ellen (Nov 16, 2007), The Multinational Force Mandate, in Global Policy Forum Journal, Princeton University, Princeton

[4] Khan Ali (July 2003), Lawlessness in Iraq and the Failure of Unilateralism, Washburn University - School of Law Press, Washburn

[5] Tremblay Rodrigue (Jun 18, 2008), The Illegitimate and Disastrous U.S. Military Occupation of Iraq, Atlantic Free Press

[6] Roberts, A (2005), What is a Military Occupation, in Ben Clarke(Aug 2005) Military Occupation and the Rule of Law: The Legal Obligations of Occupying Forces in Iraq, Murdoch University Electronic Journal of Law, Murdoch

[7] Joffe Alexander, (Mar 2004), Museum Madness in Baghdad, Middle East Quarterly Journal, Philadelphia

[9] Knickmeyer Ellen (Feb 23, 2006), Bombing Shatters Mosque in Iraq, in The Washington Post Newspaper

[10] Croke Lisa Ashkenaz (Apr 27, 2007), Abuse, Torture and Rape Reported at Unlisted U.S. -run Prisons in Iraq, The New Standard Newspaper

[11] Rosen Ruth (Jul 13, 2006), The Hidden War on Women in Iraq, Common Dreams Journal, USA

[12] Brown Mike (Jul 13, 2006), Guantánamo Trials Ruled illegal, The Guardian, United Kingdom

[13] Hartmann Tom (Jun 19, 2006), Reclaim the Issue - Occupation, Not War, in Common Dreams Journal, USA

[14] Sengupta Kim (Aug 18, 2007), Medical Crisis in Iraq as Doctors and Nurses Flee, in the Independent World Newspaper 